\title{
Válvula H.O.P.E.: Un nuevo rediseño de la válvula Charlotte para atender a pacientes con COVID-19
}

\section{H.0.P.E. valve: A newly redesign of the Charlotte valve for taking care of COVID-19 patients}

Sr. editor:

Desde la introducción de la válvula Charlotte ${ }^{1}$ como una adaptación alternativa y compasiva para una oxigenación CPAP $^{2}$ no aerosolizante en pacientes con COVID-19, varios informes de Italia, España y otros países muestran que la adaptación de la máscara de snorkel no solo funcionó como se esperaba sino evitó que también los pacientes se deterioren cuando se usaba adecuadamente en etapas tempranas e intermedias de la enfermedad recién descubierta.

En los países en desarrollo, los sistemas de salud suelen colapsar, y las oportunidades para tener una cama de UCI disponible con ventilación mecánica son casi nulas. Esto es particularmente cierto en el contexto de la pandemia actual relacionada con el SARS-CoV-2. En ese sentido, cualquier esfuerzo por intervenir tempranamente $\mathrm{y}$ proporcionar apoyo de oxigenación / ventilación a los pacientes con COVID-19 es crucial para prevenir su deterioro clínico y la admisión a la UCI.

Presento un nuevo diseño de válvula llamado H.O.P.E. ${ }^{3}$ Se ha construido desde cero como un monobloque, incorporando las mejores características de la válvula Charlotte y agregando otras características descritas a continuación (Figura 1).

I La válvula Charlotte fue ideada por el Dr. Renato Favero, en Italia. Él fue el precursor en la adaptación de este aditamento para ofrecer CPAP sin aerosolización a los pacientes con COVID-19. El diseño original incluyó dos ramas, una inhalatoria y otra exhalatoria con conectores para el acople de tubos corrugados que, a su vez, se unen con los sistemas de oxígeno y bolsa reservorio en el terminal de ingreso; $y$, filtro antiviral/antibacteriano más la válvula PEEP en el terminal exhalatorio. Es un modelo funcional pero el paciente tiene que portar varios elementos colgantes sobre la cabeza.

2 CPAP es la forma preferida de apoyo ventilador no invasivo en el manejo del paciente COVID-19 hipoxémico, no sustituye la ventilación mecánica invasiva (VMI) pero la aplicación temprana puede proporcionar un puente a VMI.

3 H.O.P.E. no es un acrónimo. Es el nombre de una iniciativa.
Guzmán-Del-Giudice, O. Válvula H.O.P.E.: Un nuevo rediseño de la válvula Charlotte para atender a pacientes con COVID-19. Rev Soc Peru Med Interna. 2019;33(2):91 .

https://doi.org//0.36393/spmi.v33i2.530

Las ventajas de esta nueva válvula incluyen: un diseño compacto, elegante y optimizado con el puerto de exhalación en la parte superior del monobloque; dos puertos de oxígeno integrados, permitiendo un flujo de hasta 30L / min; es más cómodo en un paciente recostado en posición de decúbito prono, y tiene menos objetos colgando sobre la cabeza tales como tubos, válvulas PEEP, etc. Está preparada tanto para uso hospitalario como extrahospitalario, donde sólo hace falta un balón de oxígeno que pueda proveer flujos de $15 \mathrm{~L} / \mathrm{min}$, haciendo simple su ensamblaje y utilización. Por esta razón incorporamos dos tomas tipo nipple, para que con líneas simples de oxígeno se pueda ofrecer alto flujo y CPAP en cualquier escenario clínico. La Válvula H.O.P.E. tiene internamente dos flujos, uno inhalatorio (que es alimentado por las tomas nipple embebidas en la válvula -flechas rojas-, y uno exhalatorio que se conecta al filtro antiviral/antibacteriano más válvula PEEP (Figuras 1-3).

Espero que este diseño inspire a otros a seguir innovando y buscando soluciones creativas en entornos de escasos recursos.

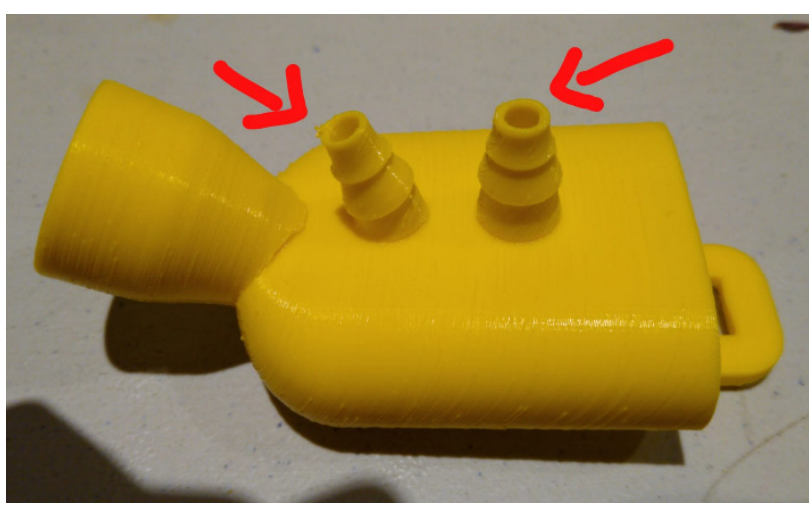

Figura I. 


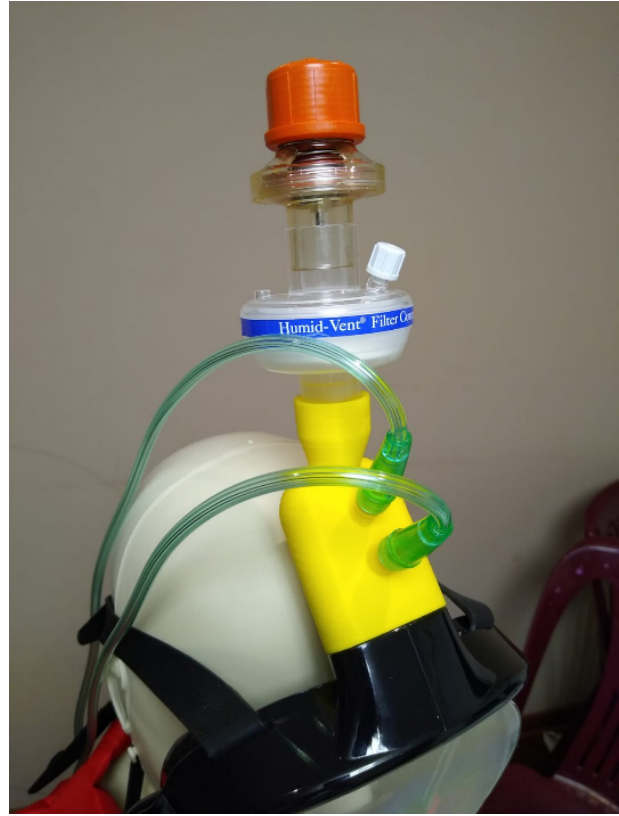

Figura 2.

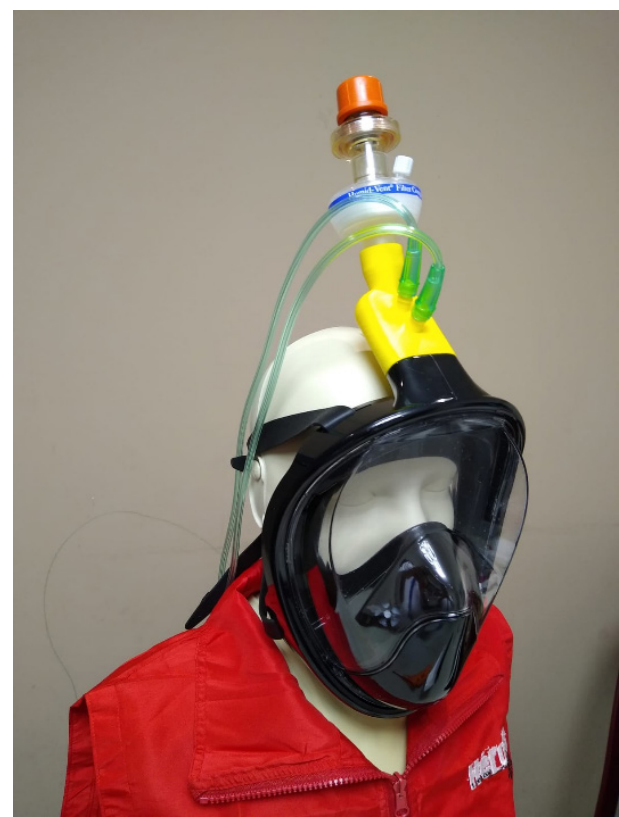

Figura 3.

\section{BIBLIOGRAFÍA}

I. H.O.P.E. www.unalientodeesperanza.org

2. https://www.isinnova.it/easy-covid/9-eng/

3. https://www.tgcom24.mediaset.it/cronaca/coronavirus-lamaschera-di-snorkelingsi-trasforma-in-un-respiratore-uno-degliideatori-a-tgcom24-piccoli-gesti-possono-f_I6465I 5I-202002a. shtml

Médico asistente. Departamento de Emergencia, Clínica Delgado, Lima. Iniciativa H.O.P.E. "Un aliento de esperanza"

\section{H.O.P.E. valve: A newly redesign of the Carlotte valve for taking care of COVID-19 patients}

Dear editor,

Since the introduction of the Charlotte valve ${ }^{4}$ as an alternative and compassionate adaptation for a nonaerosolizing CPAP $^{5}$ oxygenation in COVID-19 patients, there has been many reports from Italy, Spain and other countries showing the snorkel mask adaptation not only worked as expected, but also prevented patients to deteriorate when used properly in early and intermediate stages of the newly discovered disease.

In developing countries, health systems are usually collapsed, and opportunities for having an available ICU bed with mechanical ventilation is almost none. This is particularly truth in the context of the current pandemic related to SARS-CoV-2. In that sense, any effort to early intervene and provide oxygenation/ventilation support to COVID-19 patients is crucial to prevent their clinical deterioration and ICU admission.

I introduce a new valve design named H.O.P.E. ${ }^{6}$ It has been built from scratch as a monoblock, incorporating the best features of the Charlotte valve and adding other features listed lines below (Figure 1).

Advantages of this new valve include: A compact, stylish and optimized design with the exhalation port in the upper part of the monoblock; two oxygen ports embedded, allowing a flux of $30 \mathrm{~L} / \mathrm{min}$; it is more comfortable whenever a patient is lying down on prone position, and there are less objects hanging over the head like tubing, PEEP valve, etc. The H.O.P.E. valve has internally two flows, one inhalation (which is fed by the nipples embedded in the valve -red arrows-, and an exhalation that connects to the antiviral/ antibacerial filter plus PEEP valve (Figures 1-3).

I hope this design inspire others to keep on innovating and looking for creative solutions in scarce resource environments.

Oscar Enrique Guzmán-Del-Giudice '

CORRESPONDENCIA

oguzman@auna.pe, dr.oscar.guzman@gmail.com

4 The Charlotte valve was devised by Dr. Renato Favero in Italy. $\mathrm{He}$ was the forerunner in adapting this attachment to offer nonaerosolizing CPAP to patients with COVID-19. The original design included two branches, one inhaler and one exhalation with connectors for the coupling of corrugated tubes that, in turn, are joined with the oxygen and reservoir bag systems at the inlet terminal; and, antiviral/antibacterial filter plus the PEEP valve in the exhalation terminal. It is a functional model but the patient has to carry several hanging elements on the head.

5 CPAP is the preferred form of non-invasive ventilator support in the management of the hypoxemia COVID-19 patient, it is not a substitute for invasive mechanical ventilation (IMV) but early application can provide a bridge to it.

6 H.O.P.E. is not an acronym. It's the name of an initiative. 